\title{
Is Magic a Serious Research Topic? Reflexions On Some French Students' Remarks About Magic in Psychology
}

\author{
Pascal Morchain* \\ Psychology Department, France \\ *Corresponding author: Pascal Morchain, Psychology Department, France
}

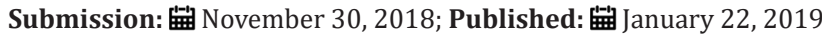

\section{Short Communication}

This paper investigates the reasons for which some students in psychology curriculum seem to be not interested in the theme of magic as a research topic. Contextual factors are evoked, but this apparent disinterest is also interpreted in terms of representations of psychology, representations of magic, historical factors, and in terms of social value of the topic.

Is magic a serious research topic? This question seems a bit weird. Obviously, in psychology show magic is a very serious topic. It deals with psychological processes, and with social interactions. In the late $19^{\text {th }}$ century and early $20^{\text {th }}$ century, famous psychologists as Binet [1,2]; Jastrow [3]; Triplett [4] use magical performances to understand psychological functioning. In 1999 Lamont \& Wiseman [5] published Magic in theory, a theoretical book analysing the art of magic. Between 1887 and 1999, only 12 empirical articles about perception of magic in adults were published; they were 55 between 2000 and 2016 [6]. Nowadays, this field is sometimes called "science of magic" [7,8] or, most specifically, "neuromagic" [9]. In psychology, magic can be studied as any other object, or can be a mean to study psychological processes [10]. To our knowledge, most studies deal with perception and cognitive psychology $[11,12]$ and very few with social psychology $[13,14]$.

As a psychology teacher, I frequently receive students who want me to be their research director for the study and the report they have to achieve in their curriculum (L3 and M1 that is, bachelor and master). All psychology students know, because it figures on my academic profile as a social psychologist, that magic is now my only research topic. As I previously worked on stereotypes, discrimination, and social contexts of influence, they come to me with some expectancies. To illustrate, let me give you two examples of interactions I have with most of them. Student: "I'm coming to you, because I want to work on sexual discrimination in hiring/ in work". Me: "Okay, we will work on sexual discrimination in the hiring of magicians vs female magician/in the fees of magicians vs female magicians”. Student: “Oh... Well... Hem... It's interesting, but finally I cannot work with you. I want to study sexual discrimination in hiring/in work". Second and last example: Student: "I'm coming to you, because I want to work on inattentional blindness". Me: "Okay,

we will work on social factors affecting inattentional blindness in a magical context". Student: "Oh... Well... Hem... It's interesting, but finally I cannot work with you. I want to study inattentional blindness". I could write many pages about these examples, but it would always be the same discourse. For the most of these students indeed, it seems that magic is not a "serious" research topic in psychology. This conception seems to be specific of our psychology students, because many students from other curricula than psychology worked with me on research on magic.

Of course, the reactions of our psychology students are conditioned by the context: the university they are in, the way psychology is taught, and the fact that most of the time, the topic they have to investigate at this stage of their curriculum is very rarely dictated by the research director. But other reasons can be hypothesized. All are to be linked with the representations of psychology, of the art of magic, and probably most widely with representation of artistic professions. More generally, I think they are linked with the value attributed to the research topics in psychology.

Firstly, it seems that for most of our students, "psychology" mainly refers to "clinical psychology", which only seems to mean "psychopathology", which only would mean "psychoanalysis", limited to Lacan's approach. That is specific to our university, and of course this representation is not homogeneous. Most of our students are moving towards clinical psychology or work psychology. Conversations with some students let me think that our students forget that a clinical approach means, too, an individual approach. In that sense, Piaget's work on child development [15] is a clinical one. They seem to forget that psychology explore mental functions/processes and individual or social behaviors. They seem to forget that a psychologist has to support is reasoning on different theoretical knowledge and on a large range of methodology of research. They seem to forget too, that psychology provides explanations at different levels [16].

Furthermore, and specifically about magic, our students seem to believe that magic is "only" an entertainment. They seem to forget that, on the one hand the practice of an art is, too, a work that 
involves psychological processes and contents (including learning, schemas, motor patterns, representation of goals etc.); on the other hand, that magicians too are workers earning money, at least the full-time or part-time professionals' ones. As a work activity, magic too can be addressed in social psychological terms. Students seem to forget that practicing magic is a social activity that has a history, is socially evaluated, is related to beliefs, etc. And they forget that psychologists, as therapists, can use magic as a tool to help people to develop motor skills, assertiveness, positive self-image, openness to others, creativity, etc. (these examples only refer to my personal experience as a part-time professional magician, and must be investigated in psychological research). In my opinion, our students also "forget" because of us, their psychology teachers (most of us in our university), are not interested in magic as a research theme. But that may be specific of our university. Wider, that may be since for this moment, magic is a relatively little developed field of research comparatively to other topics. Indeed, a historical perspective leads me to think that a topic is determined by history and by available techniques. So, in psychology several points of interest (or levels of analyses) have been addressed according to the period (for example Freud's psychoanalytic model, perceptive thresholds, priming, majority vs minority effects, obedience to authority, discrimination etc.). Maybe historically speaking, magic is a too (apparent) young topic.

It is possible that students perceive magic as a too specific topic unrelated to psychology. For example, in France, magic seems to be first and automatically conceived as an entertainment, specifically for kids. As a part-time professional magician, I frequently ear such remarks. Moreover when I propose, as a social psychologist, to a library or a cultural place a conference on historical and psychological aspects of magic, people frequently answer: "Oh, "magic" ... Well ... No thank you. Here we are a cultural place. But we could be interested in a show for kids". So, some themes are defined as cultural ones (sculpture, painting, theatre etc.), other not. Of course, this is not the case everywhere, some people think magic as a very seminal topic [17]. But because of this social definition, our students too, probably think that magic is not a very serious research theme.

Linked to the previous reasoning, I think that one of the main reasons of this perception is the social value of magic as a research topic. It is well known that the concept of "value" underlies human activities and perception [18-21]. Value is a polysemic construct [22], and in this paper it refers to Beauvois' model [23,24], which postulate that people may be evaluated according to a bidimensional model. So, people may be perceived as more or less "socially useful" (social utility dimension), i.e. they are yielding money, as economically important. But people can be too perceived as "socially desirable" (social desirability dimension), i.e. they are seen as more or less "likeable". This bi-dimensional model is different but close to the Fiske's warmth-competence model [25].

These two models are useful to investigate person perception, stereotypes, but are useful also to describe the way other targets are perceived, for example animals [26-28]. For example, as a job magic is conceived as more socially desirable than socially useful $[28,29]$. In other words, it seems to be perceived as a sympathetic job, but not very economically profitable. It may be the case for other artistic professions, but probably not for all [30] and that perception may depend on cultural factors. Furthermore, research contracts with institutions refer to other fields than magic (discrimination, security, car driving, terrorism, conspiracy theories, education, etc.). So, this perception of the social value of magic may influence students in their choice of research topic. Probably for psychology students (at least ours), a research report about magic may not seem very lucrative for their future curriculum and job, comparatively to a report on other professions (lawyer, accountant, seller, surgeon, etc.). So, the topic of sexual discrimination in hiring or in jobs seems to be perceived as a profitable theme but not sexual discrimination in artistic professions. More largely this reasoning applies to many other topics in psychology. Concerning the question of the representation of the topic, I think interesting to notice the latter fact. I observed that, when I describe the relation between a student and a research director as a "winner-winner" relation (the director teaches a method, a way of thinking and working, and the student contributes to the studies of his teacher, who must publish in his field), more students accept to work on the topic of magic. Moreover, as a teacher, for two years my strategy is now to systematically present the results of my different studies in psychology courses, first to illustrate a methodology of research or social psychological phenomena/processes, second to initiate discussions with my students. And I systematically-and if possible, more and more- insist on the fact that, for psychologists, the most important is the validity of the process.

In the future, on the one hand it would be of great interest to investigate the field of social value attributed to different research topics in psychology, first in students beginning the psychology curriculum in our university. Questionnaires will be built to this purpose. In my lab, and in collaboration with another lab (LAPCS: Laboratoire d'Anthropologie et de Psychologie Cognitive et Sociale, EA 7278, University of Nice- Sophia Antipolis), I began a series of studies with colleagues in cognitive and social psychology, trying to more implicate students in the topic of social determinants of inattentional blindness and change blindness [31,32], two processes implicated in magic. On the second hand, without denying the great importance of studies about magic in cognitive psychology, it would be rich to persevere in the study of magic in other fields of psychology, like developmental psychology [33,34]. In this field, in collaboration with a colleague and one student of us, I first ran a study on the link between the theory of mind and the perception of magic in children [35]. Finally, I now want to develop my studies in social psychology, for example about the link between group identity and perception of magic [36], or about the social value and fees attributed to a magician according to his. Her gender [37]. Students or not, "show must go on".

\section{References}

1. Binet A (1894) La psychologie de la prestidigitation [Psychology of legerdemain]. Revue des deux Mondes, 25, 64 ${ }^{\text {eme }}$ année [64 $4^{\text {th }}$ year] $903-$ 922.

2. Thomas C, Didierjean A, Nicolas S (2016) Scientific study of magic: Binet's pioneering approach based on observations and chronophotograpy. Am J Psychol 129(3): 315-328. 
3. Jastrow J (1897) Magic stage illusions and scientific diversions, including trick photography. Science 6: 850-851.

4. Triplett N (1900) The psychology of conjuring deceptions. American Journal of Psychology 11(4): 439-510.

5. Lamont P, Wiseman R (1999) Magic in theory: An introduction to the theoretical and psychological elements of conjuring. University of Hertfordshire Press, Hatfield, UK.

6. Science of magic association. https://scienceofmagicassoc.org/

7. Kuhn G, Amlani AA, Rensink RA (2008) Towards a science of magic. Trends Cogn Sci 12(9): 349-354.

8. Lamont P, Henderson JM, Smith TJ (2010) Where science and magic meet: The illusion of a "science of magic". Review of General Psychology 14(1): 16-21

9. Macknik SL, Martinez S, Blakeslee S (2010) Sleights of Mind. Holt, New York, USA.

10. Rensink RA, Kuhn G (2015) A framework for using magic to study the mind. Front Psychol 5: 1508.

11. Raz A, Olson JA, Kuhn G (2016) The psychology of magic and the magic of psychology. Frontiers Media, Lausanne, Switzerland.

12. Thomas C, Didierjean A (2016) Magicians fix your mind: how unlikely solutions block obvious ones. Cognition 154: 169-173.

13. Nardi PM (1988) The social world of magicians: gender and conjuring. Sex Roles 19(11-12): 759-770.

14. Morchain P (2019) Gendered representations of professions on the Internet. The example of show magic Gender representations of occupations on the Internet. The example of Magic Show. Communications, 36/2.

15. Piaget J (1932) Moral judgment in children. Presses University of France, Paris.

16. Doise W (1986) Levels of explanation in social psychology. Cambridge University Press, Cambridge, UK.

17. Morchain P (2017) Magic and psychology. When our perceptions play us tricks. In: J Serrano (eds). Magic, a challenge to our intelligence, One Thousand Thousand Million-Descartes \& Cie, Maurepas, France, Pp. 135-154.

18. Spranger E (1922) $3^{\text {rd }}$ edn Types of men; the psychology and ethics of personality by Eduard Spranger. Authorized translation of the fifth German edition; Life forms: psychic psychology and personality ethics. Niemeyer.

19. Allport GW, Vernon PE (1931) A study of values. Houghton Mifflin, Boston, USA.

20. Osgood CE, Suci GJ, Tannenbaum PH (1957) The measurement of meaning. University of Illinois Press, Chicago, USA.

21. Schwartz SH (1992) Universals in the content and structure of values: theoretical advances and empirical tests in 20 countries. In: M Zanna (eds), Advances in experimental social psychology, Academic Press, Orlando, Florida, USA, 25: 1-65.
22. Rohan MJ (2000) A rose by any name? The values construct. Personality and Social Psychology Review 4(3): 255-277.

23. Beauvois JL (1995) La connaissance des utilités sociales [Knowledge of social utilities]. Psychologie Française 40(4): 375-387.

24. Dubois N (2010) Theory of the social value of persons applied to organizations: Typologies of "good" leaders and recruitment. European Review of Applied Psychology/Revue européenne de psychologie appliquée 60: 255-266.

25. Fiske ST, Cuddy AJC, Glick P (2007) Universal dimensions of social perception: Warmth, then competence. Trends in Cognitive Science 11(2): 77-83.

26. Dubois N, Beauvois J (2011) Are some rabbits more competent and warmer than others? the lay epistemologist is interested in object value, not in descriptive parameters. Swiss Journal of Psychology 70(2): 63-73.

27. Sevillano V, Fiske ST (2016) Animals as social objects. groups, stereotypes, and intergroup threats. European Psychologist 21(3): 206217.

28. Le Barbechon E, Cambon L, Lavigne F (2005) Désirabilité et utilité sociale de 308 adjectifs de personnalité et 297 professions. L'Année Psychologique, 105 (2): 307-322.

29. Morchain P (2018) Stéréotype et valeur sociale des professions. L'exemple de la magie de spectacle [Stereotypes and social value attributed to a profession. The example of Show Magic]. Rennes, Rennes2 University, Manuscript to be submitted.

30. Amar A (2018) Valeur sociale des métiers artistiques: comparaisons entre la magie et la danse [Social value of artistic jobs: comparisons between magic and dance]. Rennes, Rennes2 University, Unpublished research report under the direction of P Morchain.

31. Morchain P, Poisson A, Devinck F (2016) The role of social beliefs in inattentional blindness : when the gorilla is seen in the midst. Research report, Rennes2 University, Rennes, France.

32. Morchain, P, Schadron G, Tréton R (2018) How did the magician retrieve your card? Social situation and Change Blindness. Research report, Rennes2 University, Rennes, France.

33. Subbotsky E (2014) The belief in magic in the age of science. Sage Open $4: 1-17$

34. Olson JA, Demacheva I, Raz A (2015) Explanations of a magic trick across the life span. Front Psychol 6: 219.

35. Morchain P, Lacroix A, Guillot S (2018) Theory of the mind and the perception of magic in children from 4 to 9 years, manuscript submitted.

36. Bouttier H (2015) Catégorisation sociale et perception d'un tour de magie, du magicien, et du cachet attribué. [Social categorization and perception of a magic trick, of the magician performing the trick, and of the fees attributed to him]. Rennes, Rennes2 University, Unpublished L3 research project under the direction of P Morchain..

37. Morchain P (2019) Une magicienne vaut-elle moins qu'un magicien? [Is a female magician less valued than a magician?]. Rennes, Rennes2 University, Research report to be submitted.
Creative Commons Attribution 4.0 International License

For possible submissions Click Here

\section{Submit Article}

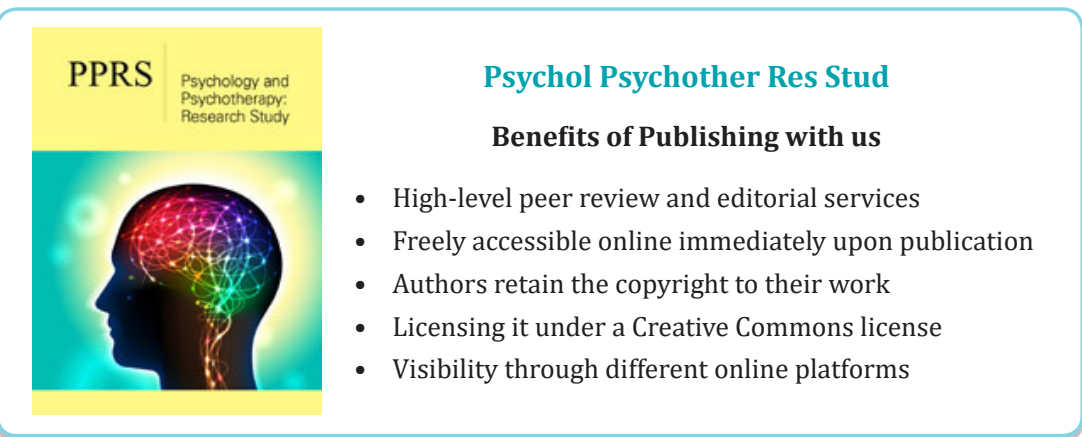

